\title{
ВЛИЯНИЕ БАЗИСНОЙ ПРОТИВОВОСПАЛИТЕЛЬНОЙ И БИОЛОГИЧЕСКИ АКТИВНОЙ ТЕРАПИИ НА КОНТРОЛЬ ГЛИКЕМИИ У ПАЦИЕНТА, СТРАДАЮЩЕГО СОЧЕТАННОЙ ПАТОЛОГИЕЙ (САХАРНЫЙ ДИАБЕТ 1 ТИПА И ЮВЕНИЛЬНЫЙ ХРОНИЧЕСКИЙ АРТРИТ).
}

\section{Силаева М.Д., Витебская А.В.}

ФГАОУ ВО Первый МГМУ им.И.М.Сеченова Минздрава России, г. Москва

Актуальность. Хронические воспалительные и аутоиммунные заболевания приводят к декомпенсации углеводного обмена при сахарном диабете 1 типа (СД1). Современные методы терапии позволяют в короткие сроки добиваться уменьшения воспаления и облегчения клинических проявлений, поэтому влияние этих препаратов на компенсацию СД1 требует изучения.

Цель исследования: изучить влияние базисной противовоспалительной (метотрексат) и биологически активной (инфликсимаб) терапии при лечении ревматоидного артрита на уровень гликемии у пациента с СД1.

Методы: Пациентка 14 лет с СД1 на протяжении 7 лет, НbА1c 7,1\%, обследована на момент манифестации ювенильного хронического артрита (ЮХА). Инсулинотерапия в базисно-болюсном режиме, суточная доза за период наблюдения 0,7-0,8 Ед/кг/сут. Постоянно проводимый флешмониторинг гликемии позволил оценить уровень среднесуточной гликемии, количество эпизодов гипогликемии на протяжении 5 дней за 2,5 месяца до манифестации ЮХА (максимально ранние показатели гликемии по данным флеш-мониторинга, доступные для анализа), на фоне максимальных клинических проявлений ЮХА (за 5 дней до начала противовоспалительной терапии) и на фоне лечения ЮХА (5 дней после первого введения метотрексата и 5 дней после первого введения инфликсимаба).

Результаты и обсуждения: По данным флеш-мониторинга средняя суточная гликемия до манифестации ЮХА составила 8,2 +/- 1,9 (4,5-11,7) ммоль/л, на фоне максимальных клинических проявлений ЮХА отмечено повышение среднесуточной гликемии 11,4+/- 2,5 (8,6-14,8 ммоль/л), с последующей нормализацией после первого введения метотрексата 7,4+/-1,2 (5,4-8,3) ммоль/л; добавление биологической терапии не оказало существенного влияния на данный показатель $8,3+/-1,2$ $(6,7-9,5)$ ммоль/л. Также наряду со снижением уровня суточной гликемии, отмечено увеличение количества эпизодов гипогликемии: 2 эпизода за 5 дней до терапии, 7 за первые 5 дней лечения метотрексатом, 3 эпизода за первые 5 дней биологической терапии (для сравнения за анализируемые 5 дней до манифестации ЮХА отмечено 6 эпизодов гипогликемий),

Выводы: Тенденция к нормализации гликемии отмечалась с первых дней начала терапии метотрексатом. Добавление биологически активной терапии не оказало существенного влияния на гликемию. 